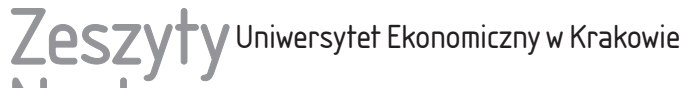 Naukowe
}

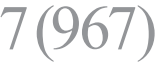

ISSN 1898-6447

Zesz. Nauk. UEK, 2017; 7 (967): 67-86

DOI: 10.15678/ZNUEK.2017.0967.0705

\section{Orientacja zasobowa w praktyce zarządzania przedsiębiorstwami - omówienie wyników badań empirycznych}

\section{Streszczenie}

Jedną z konsekwencji powstania gospodarki opartej na wiedzy było pojawienie się teorii zasobowej oraz zwrócenie uwagi na znaczenie zasobów niematerialnych organizacji. Redefinicja zasobów spowodowała powstanie wielu propozycji ich klasyfikacji i nowe rozumienie pojęcia odwołujące się do ich specyficznych cech.

Celem opracowania było dokonanie syntezy dorobku literaturowego w zakresie specyfiki zasobów niematerialnych i udzielenie odpowiedzi na pytanie, czy w opinii respondentów w przedsiębiorstwach, w których pracują, występuje orientacja zasobowa.

Wyniki analiz empirycznych potwierdziły dominację podejścia zasobowego w praktyce zarządzania organizacjami. Wskazały również na rosnącą świadomość konieczności orientacji na zarządzanie zasobami niematerialnymi. Źródeł trwałej przewagi konkurencyjnej organizacji obecnie oraz w przyszłości upatruje się najczęściej w kompetencjach, postawach i zachowaniach pracowniczych, wizerunku firmy oraz relacjach.

Słowa kluczowe: gospodarka oparta na wiedzy, zasoby niematerialne, teoria zasobowa, strategia organizacji, badania empiryczne.

Klasyfikacja JEL: L21, L250.

Anna Pietruszka-Ortyl, Uniwersytet Ekonomiczny w Krakowie, Wydział Zarządzania, Katedra Zachowań Organizacyjnych, ul. Rakowicka 27, 31-510 Kraków, e-mail: pietrusa@uek.krakow.pl 


\section{Wprowadzenie}

Wzrost zainteresowania problematyką zasobów niematerialnych organizacji jest konsekwencją synergicznego oddziaływania co najmniej kilku czynników: powstania gospodarki opartej na wiedzy cechującej się przede wszystkim redefinicją zasobową, poszukiwania nowych źródeł osiągania trwałej przewagi konkurencyjnej czy dynamicznego rozwoju badań nad raportowaniem dotychczas nieuchwytnych elementów determinujących sukces organizacji.

Powstanie gospodarki opartej na wiedzy spowodowało, że intensywnie zaczęto poszukiwać odpowiedzi na pytanie, jak sprostać wyzwaniom dotyczącym kształtowania przewagi konkurencyjnej organizacji działających w warunkach nowej ekonomii. Coraz częściej podkreślano, że w sytuacji turbulencji otoczenia należy poszukiwać podstaw strategii organizacji i źródeł jej pozycji nie na zewnątrz, ale wewnątrz przedsiębiorstwa (zob. [Wit i Meyer 2007, s. 144]). Powszechne stało się przekonanie, że w sytuacji nieprzewidywalnego, dynamicznego i zmiennego współczesnego otoczenia bardziej stabilną podstawą strategii organizacji jest jej wnętrze, czyli zasoby [Grant 1991].

Tezy te stanowiły przyczynek do powstania podejścia zasobowego w zarządzaniu jako najmłodszej ze szkół zarządzania strategicznego, powszechnie traktowanej jako nurt badawczy, a nie moda czy trend. Jej założenia pretendują do miana paradygmatycznych i wpisują się w paradygmaty nowej gospodarki ${ }^{1}$. Dynamiczny rozwój teorii zasobowej uwypuklił z kolei znaczenie zasobów niematerialnych organizacji (zob. [Abu Bakar i Ahmad 2010, s. 420; Hidayati i in. 2012, s. 1 i 3; Sequeira, Fernández i Borges 2009, s. 18; Kamasak 2017, s. 252]).

Istotą zadań stawianych zarządzającym organizacjami jest obecnie koncentracja na takich zasobach, które są głównym elementem współtworzenia wartości organizacji - dobrach zwykle nietrwałych, dostępnych na żądanie, często poza firmą w ramach sieci. W teorii zwykle są nimi zasoby niematerialne, jako te, które mają określać i warunkować wielkość potencjału kreowania wartości i w rezultacie przyszłość konkurencji (zob. [Marr 2005, s. 148; Diefenbach 2006, s. 408-409; Kristandl i Bontis 2007, s. 151; Shakina i Barajas 2015, s. 737]).

Ważne wydaje się sprawdzenie zakresu orientacji zasobowej w praktyce zarządzania organizacjami i tym samym znalezienie odpowiedzi na pytanie, czy zarządzanie zasobami niematerialnymi (i jakimi konkretnie) mieści się w obszarze percepcji zarówno zarządzających, jak i pracowników współczesnych przedsiębiorstw. Stąd celem opracowania jest przedstawienie rozwoju orientacji zasobowej przedsiębiorstwa w świetle literatury przedmiotu oraz weryfikacja hipotezy

1 J. Barney, D.J. Ketchen Jr. i M. Wright w opracowaniu pt. The Future of Resource-based Theory: Revitalization or Decline? [2011] dowodzą, że koncepcja zasobowa jest teorią. 
o orientacji na rozwój zasobów niematerialnych w zarządzaniu współczesnymi przedsiębiorstwami na podstawie przeprowadzonych badań

\section{Geneza oraz podstawowe założenia teorii zasobowej}

U początków zasobowej teorii firmy znalazło się kilka koncepcji: teoria wzrostu firmy, teoria zależności zasobowej przedsiębiorstwa czy zasobowe podejście do trwałej przewagi konkurencyjnej. Jej aktualna formuła powstała w odpowiedzi na potrzebę kompletności analizy strategicznej, dostarczając aparatu narzędziowego do oceny stanu przedsiębiorstwa [Czakon 2010, s. 8].

Teoria zasobowa stanowi jedno z czterech fundamentalnych podejść do strategii ${ }^{2}$, które ma ugruntowane podstawy dyskursywne i empiryczne. Początkowo w literaturze przedmiotu dominowały rozważania o charakterze teoretycznym [Galbreath 2005, s. 979], ale wraz z rozwojem koncepcji weryfikowano jej założenia w praktyce, czego dowodem są badania opisane w pracach takich autorów, jak: B. Villalonga [2003, s. 205-230], J. Galbreath [2005, s. 979-987], O. Kumulu [2014, s. 24-34], L. Basso i in. [2015, s. 73-83].

Teoria opiera się na założeniu, że wzrost zależy od dopasowania zasobów przedsiębiorstwa do rynkowych szans, a firma rozwija produkty i usługi zgodne z jej kompetencjami. Sama organizacja jest traktowana jako zbiór zdolności i zasobów, które mają generować rentę ekonomiczną [Gancarczyk 2015, s. 13-14].

Źródłem przewagi konkurencyjnej według tej teorii są zatem: zasoby materialne, zasoby niematerialne, kompetencje wykorzystania zasobów do tworzenia wartości, wiedza oraz umiejętności uczenia się, umiejętność celowego zmieniania rutyn operacyjnych [Czakon 2010, s. 9-10]. Zwolennicy tej koncepcji promują więc tezę, że różnice między przedsiębiorstwami w osiąganych wynikach są rezultatem ich wyposażenia w unikatowe zasoby, które determinują ich pozycję konkurencyjną, dostępne strategie i rynki, a jej fundamentalne założenie mówi o różnorodności firm [Penrose 1959, Peteraf 1993].

Teza o heterogeniczności przedsiębiorstw wyjaśnia generowanie zysków i zakłada, że organizacje różnią się od siebie pod względem posiadanych zasobów i umiejętności, te zaś różnice są właśnie źródłem określonych wyników finansowych. Istniejące trwałe różnice między przedsiębiorstwami w zakresie uposażenia w zasoby, a zarazem zdolności do osiągania ponadprzeciętnych zysków są pochodną trzech czynników: ograniczenia konkurencji ex post (silnych barier w zdobywaniu, kopiowaniu i zastępowaniu kluczowych zasobów), niedoskonałej mobilności zasobów (polegającej na tym, że nie wszystkie aktywa można kupić),

${ }^{2}$ Obok szkoły planistycznej, ewolucyjnej oraz pozycyjnej. Zob. [Obłój 2001, s. 29-30]. 
ograniczeniu konkurencji ex ante (braku informacji o tym, które aktywa będą naprawdę cenne w przyszłości) [Peteraf 1993; Zakrzewska-Bielawska 2013, s. 4; Godziszewski 2001, s. 42-49].

Analizując rozwój teorii zasobowej w czasie, należy podkreślić jej ewolucję³ O ile początkowo koncentrowano się na identyfikacji i kształtowaniu wiązki odpowiednich zasobów i teoria miała charakter bardziej statyczny, to później zaczęto akcentować jej dynamiczne aspekty. Współcześnie zwraca się uwagę na rolę zdolności jako tych z zasobów, które wpływają na zmianę pozostałych i przyczyniają się do przekształcania i tworzenia kolejnych strategicznie wartościowych zasobów [Kamasak 2017, s. 253].

Syntetycznie ujmując wkład teorii zasobowej w rozwój szkół zarządzania strategicznego, można je zestawić ze względu na kryterium: ogólnego formułowania celów, ukierunkowania i podłoża konkurencji, charakteru przewagi konkurencyjnej, orientacji strategicznej, horyzontu planowania, roli domen i zadań naczelnego kierownictwa [Moszkowicz 2005, s. 63].

Warto podkreślić, że dzięki i za sprawą teorii zasobowej rozwinęły się kolejne współczesne szkoły, nurty i koncepcje: szkoła opcji realnych [Obłój 2007], koncepcja kluczowych kompetencji, teoria wyróżniających strategicznych zdolności, nurt dynamicznych zdolności, teoria organizacji opartej na wiedzy, koncepcja organizacyjnego uczenia się, koncepcja nowych form opartych na technologii [Wojciechowska 2016, s. 93; Krupski 2014, s. 4; Zakrzewska-Bielawska 2013, s. 4].

Nie należy jednak zapominać, że sama teoria zasobowa nie jest wolna od pewnych niedostatków - tautologicznej konstrukcji (dwóch podstawowych hipotez prowadzących do pętli logicznej), braku symetrii (wynikającej z kontekstowości i humanizmu) czy dyskusyjnej przydatności praktycznej w formułowaniu i implementacji strategii (szerzej zob. [Krupski 2012, s. 5; Czakon 2010, s. 11]).

\section{Konkurencyjność zasobów niematerialnych organizacji}

Sam termin „zasoby” odwołuje się do wszystkich komponentów materialnych i niematerialnych niezbędnych organizacji do realizacji jej celów w sposób skuteczny i efektywny. J. Brilman [2002, s. 143] definiuje je jako aktywa ${ }^{4}$ (materialne i niematerialne) oraz zdolności organizacyjne decydujące o tym, co w sensie

${ }^{3}$ Założenia i wkład w rozwój teorii zasobowej poszczególnych badaczy prezentują L.J. Abu Bakar i H. Ahmad [2010, s. 424].

${ }^{4} \mathrm{~W}$ literaturze przedmiotu nie istnieje jedna powszechnie akceptowana definicja zasobów. Często zdarza się, że badacz używa określeń charakterystycznych dla dziedziny nauki, którą reprezentuje. Najczęściej specjaliści z zakresu nauk o zarządzaniu posługują się terminem „zasoby”, przedstawiciele rachunkowości stosują termin ,aktywa”, a w ramach pojęć księgowych sięga się po 
strategicznym jest w stanie zrobić przedsiębiorstwo. W konsekwencji mogą mieć charakter materialny (aktywa finansowe, rzeczowe i ludzkie) lub niematerialny (wiedza, kultura organizacyjna, reputacja, marki, relacje z otoczeniem, prawa własności intelektualnej).

J. Barney [1991, s. 99-120], przedstawiciel teorii zasobowej w zarządzaniu, charakteryzuje zasoby jako aktywa, zdolności, procesy organizacyjne, wiedzę, informacje i inne atrybuty firmy, które pozwalają budować jej strategię i poprawiać efektywność. Zakłada, że zasoby, aby stanowić podstawę efektywnej strategii i przyczyniać się do budowania trwałej przewagi konkurencyjnej danej organizacji, powinny posiadać konkretne cechy: strategiczną wartościowość (dzięki nim organizacja może wykorzystywać szanse i przeciwstawiać się zagrożeniom), rzadkość występowania (u aktualnych lub potencjalnych konkurentów), trudność do imitacji i brak substytucyjności.

Współcześnie, w warunkach gospodarki opartej na wiedzy, cechy te najczęściej przypisywane są właśnie zasobom niematerialnym ${ }^{5}$ i to zwłaszcza w nich upatruje się przyszłości w budowaniu przewagi konkurencyjnej organizacji, ujmując je nawet w koncepcji konkurencyjności zasobowej. Zasadza się ona na kształtowaniu zestawu zasobów o charakterze materialnym i niematerialnym wpływających na zdolność konkurencyjną organizacji. W ramach struktury konkurencyjności zasobowej przedsiębiorstwa wyraźnie akcentuje się nadrzędną rolę konkurencyjności zasobów ludzkich jako źródła konkurencyjności pierwotnej, inicjującej konkurencyjność wtórną - zasobów finansowych, informacyjnych, rzeczowych, wiedzy, kultury organizacyjnej, środowiska naturalnego (zob. [Leśniewski 2014, s. 57-68]).

Oprócz atrybutów zidentyfikowanych przez J. Barneya właściwości zasobów niematerialnych tworzą kolejne ich cechy (zob. szerzej [Kristandl i Bontis 2007, s. 1519; Pietruszka-Ortyl i Mikuła 2010, s. 31-46; Wojciechowska 2016, s. 95]):

- zasoby niematerialne same w niewielkim stopniu przyczyniają się do kreacji wartości czy generowania wzrostu - by determinowały rozwój organizacji, powinny być łączone z zasobami materialnymi, a model zarządzania przedsiębiorstwem oparty na zasobach niematerialnych powinien mieć holistyczną formułę;

- wartość zasobów niematerialnych jest ściśle związana z przyszłością organizacji - ten typ zasobów odpowiada bowiem za umiejętności i potencjał przedsiębiorstwa w zakresie wzrostu i rozwoju w przyszłości;

określenie „kapitał”. Zestawienie definicji zasobów oraz próbę usystematyzowania wymienionych pojęć prezentują opracowania [Pietruszka-Ortyl 2017, s. 129; Kristandl i Bontis 2007, s. 1513-1514].

5 Autorskie definicje zasobów niematerialnych prezentują np.: T. Diefenbach [2006, s. 409], G. Kristandl i N. Bontis [2007, s. 1518] oraz A. Hidayati i in. [2012, s. 1]. 
- zasoby niematerialne są w porównaniu z materialnymi bardziej niestabilne w przypadku spadku wartości przedsiębiorstwa wartość jego zasobów niematerialnych maleje dużo szybciej;

- jakość zasobów niematerialnych zależy od intensywności interakcji między potencjałem intelektualnym pracowników a pozostałymi aktywami, gdyż wszystkie one są budowane wokół wiedzy;

- zasoby niematerialne rzadko w bezpośredni sposób wpływają na finansowe rezultaty działalności firmy, ale mają wpływ pośredni przez efekt synergiczny relacji.

Obecnie obowiązuje systemowe podejście do zasobów, zgodnie z którym przedsiębiorstwo traktowane jest jako struktura zbudowana z zależnych od siebie części, stanowiąca wewnętrznie spójną, dynamiczną całość, współzależną od połączeń i kooperacji między jej elementami [Skowronek-Mielczarek 2012, s. 128]. Implikuje ono zatem również koncentrację na klasyfikacji samych zasobów ${ }^{6}$.

J. Barney [1991, s. 99-120] dzieli zasoby na następujące grupy:

- fizyczne - budynki i maszyny, technologia wykorzystywana w procesie produkcji, położenie geograficzne i dostęp do surowców,

- ludzkie - wyszkolenie, doświadczenie i wiedza pracowników,

- organizacyjne - struktura organizacji, planowanie, controlling, systemy koordynacji, nieformalne relacje wewnątrzorganizacyjne, związki przedsiębiorstwa $\mathrm{z}$ otoczeniem.

Wieloaspektową klasyfikację zasobów organizacji prezentuje również R. Maier [2002, s. 92-95]. Czerpie on z podziału na zasoby materialne i niematerialne, a wśród niematerialnych wyróżnia zależne i niezależne od człowieka (zob. [Pietruszka-Ortyl 2008, s. 53-70]). W uzupełnieniu autor wskazuje, jaki wpływ na pozycję konkurencyjną organizacji mają konkretne grupy zasobów. W tym celu charakteryzuje pięć wymiarów przewagi konkurencyjnej:

- przewagę funkcjonalną wynikającą z wiedzy, umiejętności i doświadczenia pracowników oraz innych osób mających wkład w tworzenie łańcucha wartości (np. dostawców, dystrybutorów, prawników itp.),

- przewagę kulturową odnoszącą się do kultury organizacyjnej przedsiębiorstwa i stanowiącą odzwierciedlenie zasad panujących w firmie,

${ }^{6}$ W literaturze przedmiotu znaleźć można wiele propozycji klasyfikacji zasobów organizacji w ramach podejścia zasobowego. Autorskie koncepcje podziału zasobów organizacji (w tym niematerialnych) prezentują np.: R. Hall [1992, s. 608-610; 1993, s. 136-139], T.A. Stewart [2001, s. X], M. Bratnicki [2000, s. 50-52], B. Lev [2003, s. 299-300], B. de Wit i R. Meyer [2007, s. 163], B. Lowendahl [Dudycz 2005, s. 221], J. Kozłowski [2002, s. 32], W. Hopfenbeck, M. Múller, T. Peisl [2001, s. 347], M.J. Stankiewicz [2002, s. 105-109], T. Diefenbach [2006, s. 413-414], A. Skowronek-Mielczarek [2012, s. 130-131], E. Shakina i A. Barajas [2015, s. 732], M. Wojciechowska [2016, s. 95]. 
- przewagę jakości zarządzania jako rezultatu zdolności innowacyjnych organizacji i umiejętności szybkiej i efektywnej adaptacji do uwarunkowań otoczenia,

- przewagę pozycyjną stanowiącą konsekwencję przeszłych zachowań rynkowych budujących reputację i kontakty z interesariuszami,

- przewagę prawną dotyczącą posiadanych zasobów własności intelektualnej chronione prawnie.

\section{Wybrane problemy zarządzania zasobami niematerialnymi}

Podstawowym zarzutem stawianym teorii zasobowej jest to, że nie skupia się na wytycznych formułowania strategii, jej implementacji czy procesie tworzenia wartości, a koncentruje się na warunkach wstępnych uzyskiwania przewagi czy mechanizmach ochrony tej przewagi przed działaniami konkurentów [Czakon 2010, s. 10]. W literaturze przedmiotu można jednak znaleźć propozycje obalające ten zarzut.

Najpowszechniejszym modelem procesu identyfikacji strategii firmy zakorzenionym w teorii zasobowej jest ten zaproponowany przez R. Granta [2001, s. 115]. Uwzględnia on pięć etapów odnoszących się do zasobów. W ramach czwartego, dotyczącego wyboru strategii, dochodzi do skonfrontowania zasobów z otoczeniem. W rezultacie wskazany zostaje niedobór jednych zasobów (luka zasobowa) i nadmiar innych (podstawa do strategii dywersyfikacji). Identyfikacja luki zasobowej determinuje orientację na pozyskanie ich wewnątrz organizacji lub z jej otoczenia oraz sposób jej zapełnienia. W ten sposób wyznaczone zostają poziom i struktura niezbędnych zasobów.

Analiza zasobów przedsiębiorstwa to w myśl teorii zasobowej główne zadanie w procesie formułowania strategii. B. Godziszewski [2001, s. 182] proces formułowania strategii ujmuje dychotomicznie, zwracając uwagę na wewnętrzną i zewnętrzną perspektywę. Pierwsza, wewnętrzna ścieżka dotyczy wyłącznie zasobów: ich analizy, oceny poziomu i potencjału. Druga, zewnętrzna, jest charakterystyczna dla otoczenia organizacji i rozpoczyna się od scenariuszy. Ścieżki te są równoległe - każdy etap ścieżki wewnętrznej jest związany z etapami ścieżki wewnętrznej - i kończą się na wyborze strategii.

Autorską propozycję identyfikacji strategii przedstawił też R. Krupski. Punktem wyjścia jest wskazanie wartościowych zasobów organizacji tworzących podstawowe wartości dla firmy i ważne dla jej klientów. Kolejno ustala się cechy zasobu w skali sektora, które determinują stopień jego oryginalności, oraz identyfikuje się umiejętności firmy warunkujące praktyczne wykorzystanie danych zasobów, gdy pojawią się ku temu okazje. Następnie dokonuje się oszacowania spodziewanych efektów wykorzystania danych zasobów w kategoriach kosztów ich utrzymania 
i rezultatów wykorzystania okazji. Na koniec wybiera się konkretny sposób pozyskania i utrwalania wartościowych zasobów (tworzenie, kształtowanie, zakup, uzyskanie dostępu). Kontekst strategii przedsiębiorstwa w ujęciu zasobowym tworzy wizja organizacji, wiążąc wszystkie wyodrębnione elementy [Krupski, Stańczyk-Hugiet i Niemczyk 2009, s. 174-175].

Gospodarowanie zasobami niematerialnymi stanowi zatem ogromne wyzwanie. Jego głównym celem jest podnoszenie wartości firmy przez tworzenie przewagi konkurencyjnej opartej na tych elementach. Wymaga więc takich działań, jak: identyfikacja i pomiar zasobów niematerialnych, ocena zależności między aktualną i przyszłą wartością organizacji a bazą zasobów, którymi dysponuje, wskazywanie aktywności generujących zasoby niematerialne oraz zarządzanie nimi [Sánchez, Chaminade i Olea 2000, s. 315]. W praktyce sprowadza się więc do identyfikacji, rozwijania oraz implementacji kluczowych zasobów w celu maksymalizacji zysków [Kumulu 2014, s. 25].

Podstawą formułowania strategii w perspektywie zasobów niematerialnych powinno być nie tylko identyfikowanie przewag konkurencyjnych, okazji i zagrożeń, ale pełna świadomość posiadanych kompetencji organizacyjnych i wiązki zasobów będących do dyspozycji. Taka wiedza umożliwi dopiero pełne wykorzystanie pojawiających się okazji [Marr 2005, s. 148].

Podsumowując, wytyczne w zakresie zarządzania zasobami niematerialnymi można sformułować następująco [Ziółkowska 2012, s. 157]:

- wykorzystanie czterech koncepcji zarządczych: zarządzania zmianą, zarządzania wartością, zarządzania strategicznego i zarządzania wiedzą;

- podejście holistyczne, ujmujące zasoby, procesy i działania kompleksowo, we wzajemnej współzależności i w szerokiej perspektywie;

- nastawienie na przyszłość (kreowanie wartości „teraz” zaowocuje wzrostem wartości ,później”);

- zmiana postrzegania czasu (odejście od prognozowania wyników i przewidywania przyszłych trendów na rzecz rozpoznawania problemów i uwarunkowań w otoczeniu);

- pragmatyzm (zarządzanie zasobami niematerialnymi ukierunkowane na użyteczność, efektywność i dostarczanie wartości dodanej);

- ciągłość procesu zarządzania umożliwiająca kreowanie trwałej wartości w długim horyzoncie czasowym (przez zapewnienie przedsiębiorstwu ciągłego rozwoju i wzrostu, kreowanie trwałej wartości dla właścicieli, innowacyjność, weryfikowanie strategii i jej założeń, monitoring otoczenia i źródeł wartości). 


\section{Orientacja zasobowa w świetle badań empirycznych}

Liczni oponenci szkoły zasobowej domagają się potwierdzenia jej założeń w praktyce zarządzania organizacjami. Dlatego część uczonych podjęła wyzwanie przeprowadzenia weryfikacji użyteczności zasobów niematerialnych oraz orientacji zasobowej w badaniach empirycznych (zob. [Villalonga 2004, s. 205-230; Galbreath 2005, s. 979-987; Zigan i Zeglat 2010, s. 597-610; Hidayati i in. 2012; Wojciechowska 2016, s. 91-110; Kamasak 2017, s. 252-275]). W polskiej literaturze przedmiotu jako pierwszy omówienia analiz dotyczących praktyki zarządzania organizacjami dokonał R. Krupski [2011, s. 196; 2014, s. 87-96]. Elementami teorii zasobowej w swoich badaniach empirycznych zajmowali się również: A. Skowronek-Mielczarek [2012, s. 127-142], E. Urbanowska-Sojkin [2013, s. 389-402], A. Zakrzewska-Bielawska [2013, s. 3-8] czy M. Kuzel [2016, s. 44-53].

Prowadzony w literaturze przedmiotu dyskurs stanowił inspirację do przeprowadzenia pilotażowych badań dotyczących orientacji zasobowej w przedsiębiorstwach oraz zakresu użyteczności zasobów niematerialnych w praktyce zarządzania organizacjami. Zdecydowano się je wykonać w dwóch etapach. Na początku ankietowani identyfikowali zasoby, które w ich opinii są decydujące dla kształtowania przewagi konkurencyjnej organizacji. Na podstawie uzyskanych odpowiedzi zbudowano listę zasobów, zarówno materialnych, jak i niematerialnych, którym ankietowani nadawali odpowiednie rangi. W ten sposób starano się wypełnić wskazywaną w literaturze przedmiotu lukę w badaniach empirycznych. Podkreśla się bowiem brak analiz weryfikujących jednocześnie wpływ zasobów materialnych i niematerialnych na funkcjonowanie przedsiębiorstw [Kamasak 2017, s. 253].

Wiosną 2017 r. przeprowadzono właściwe badania, w wyniku których uzyskano 146 kompletnie wypełnionych ankiet. W większości respondentami byli pracownicy szczebla operacyjnego i taktycznego badanych przedsiębiorstw. Menedżerowie szczebla strategicznego stanowili $15 \%$ wszystkich badanych.

Respondenci to pracownicy z średnim doświadczeniem zawodowym, z przeciętnym stażem wynoszącym cztery lata, a w charakteryzowanej przez udział w badaniach organizacji - dwa lata. Można przyjąć, że ankietowani mają wystarczający zakres wiedzy o firmie, której są pracownikami.

Analizowane organizacje reprezentowały różne profile działalności (usługi $55 \%$, usługi publiczne $-7 \%$, handel $-5 \%$, produkcja $-21 \%$, mieszane $-12 \%$ ), a średni czas ich funkcjonowania wynosił 14 lat. Były to więc przedsiębiorstwa posiadające doświadczenie, działające w różnych warunkach rynkowych.

Organizacje o usługowym profilu działalności (razem z usługami publicznymi) stanowią $62 \%$ badanych, a więc w próbie badawczej znajduje potwierdzenie teza, 
że w gospodarce opartej na wiedzy sektor usług dominuje nad sektorami wytwórczymi. W konsekwencji można było przypuszczać, że jeżeli większość stanowią firmy usługowe, to powinny reprezentować orientację zasobową w zarządzaniu, a skoro ich funkcjonowanie wpisuje się w uwarunkowania nowej ekonomii, przypuszczalnie powinny być ukierunkowane na zasoby niematerialne ${ }^{7}$.

Badane firmy były równie różnorodne pod względem wielkości - na próbę badawczą przypadło 13\% mikroprzedsiębiorstw, 32\% małych, 28\% średnich i $27 \%$ dużych organizacji. Wszystkie miały zadowalającą (w opinii ankietowanych) sytuację finansową (29\% było w bardzo dobrej, $52 \%$ w dobrej, a $19 \%$ w przeciętnej sytuacji finansowej).

Stabilna sytuacja finansowa charakteryzowanych organizacji sugerowała przyjęcie jednego z dwóch sposobów postępowania. Badane organizacje nie powinny stosować strategii gwarantujących jedynie przetrwanie, a wykorzystywać przede wszystkim strategie nastawione na rozwój. Powinny prezentować postawy otwartości, większą skłonność do ryzyka, poszukiwać nowych obszarów rozwoju. Zadowolenie z istniejącego stanu rzeczy może też jednak prowadzić do bierności i przyjmowania postaw zachowawczych. Dlatego uznano, że ważne jest uzyskanie odpowiedzi na pytanie dotyczące orientacji strategicznej, polityki w zakresie zasobów niematerialnych i materialnych oraz potencjalnych czynników determinujących obecną i przyszłą pozycję konkurencyjną badanych firm.

W poszukiwaniu jednoznacznej, choć wielowątkowej odpowiedzi na pytanie dotyczące orientacji strategicznej reprezentowanej przez organizacje w Polsce podstawą stały się kryteria różnicujące podejście zasobowe oraz ewolucyjno-rynkowe zaproponowane przez M. Moszkowicza. Biorąc pod uwagę średnią liczbę wyborów poszczególnych kryteriów, można stwierdzić, że $63 \%$ ankietowanych wskazało na orientację zasobową przedsiębiorstw, w których pracują, a 37\% na podejście ewolucyjno-rynkowe (rys. 1).

Jeśli chodzi o poszczególne czynniki różnicujące obydwa podejścia, jednoznacznie na orientację zasobową wskazywał wybór kryteriów dotyczących ogólnego formułowania celów (74\%), ukierunkowania konkurencji (75\%) oraz sposobu myślenia (68\%).

Traktowanie badanej firmy jako zbioru zdolności i zasobów, przyjmowanie za podstawę strategii długotrwałego wzrostu dzięki rozwojowi, wykorzystaniu i transferowi rdzennych kompetencji przy jednoczesnej holistycznej wizji organizacji, powodującej przeniesienie konkurencji z poziomu strategicznej jednostki

${ }^{7}$ Potwierdzenie takich zależności w wyniku przeprowadzonych badań empirycznych uzyskali L.F.C. Basso, J.A.S de Oliveira, H. Kimura i E.S. Braune [2013, s. 73-83]. W swych analizach dowiedli, że rodzaj zasobów ma znaczenie dla kształtowania wartości firmy w zależności od sektora. Zasoby niematerialne odgrywają kluczową rolę w budowaniu wartości przedsiębiorstw usługowych, a mniejszą w przypadku firm produkcyjnych. 
biznesu na poziom międzyorganizacyjny - to podstawy orientacji zasobowej uwidocznione w przeprowadzonych badaniach empirycznych.

Preferowana (65\% wskazań) jest ofensywna orientacja strategiczna, polegająca na transferze kompetencji i dalszym rozwoju starych i nowych rynków oraz intensywne kształtowanie czynników konkurencyjności. Dlatego też ankietowani jako zadania naczelnego kierownictwa najczęściej wskazywali integrację zasobów i zdolności zgodnie z określoną, całościową koncepcją formułowaną dla całej organizacji (60\% wskazań) i wyznaczenie długookresowego horyzontu planowania $(58 \%)$.

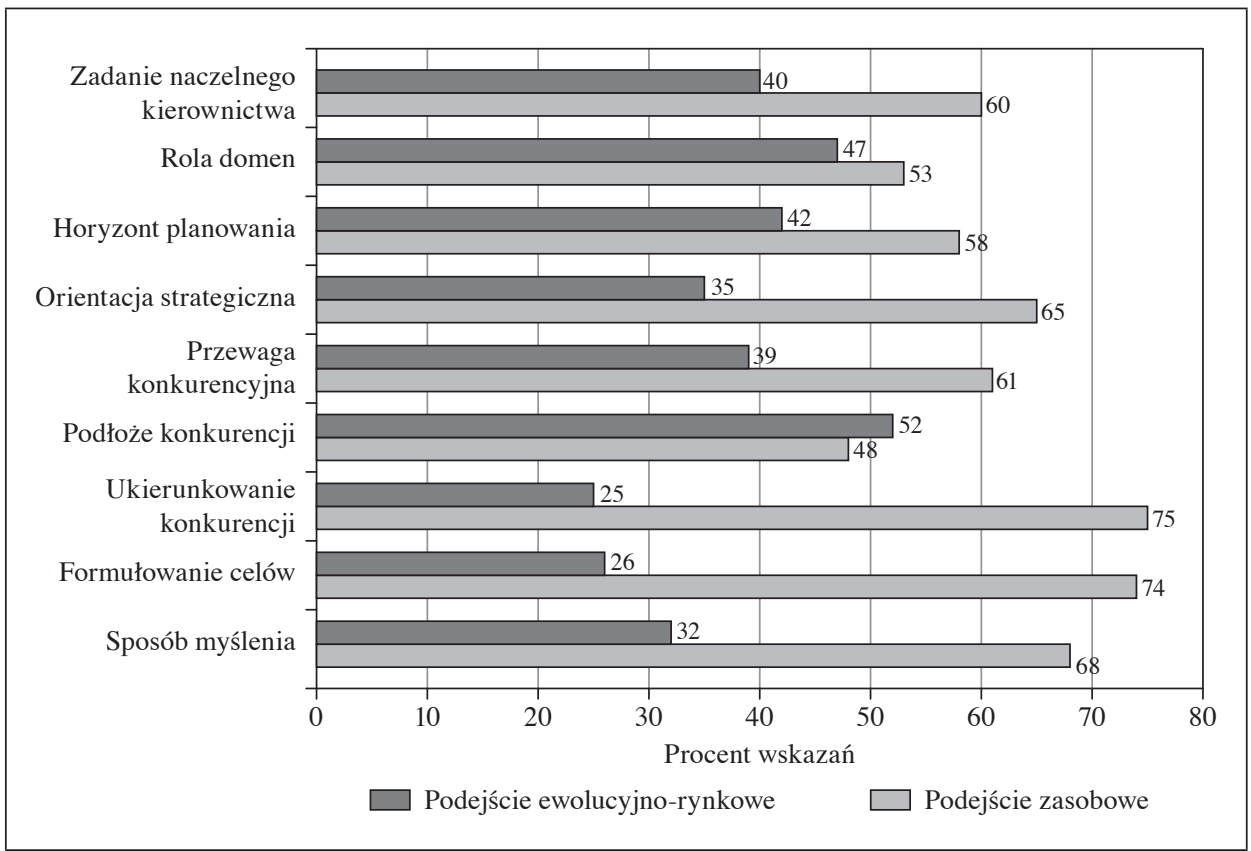

Rys. 1. Podejście zasobowe i ewolucyjno-rynkowe w świetle przeprowadzonych badań empirycznych

Źródło: opracowanie własne.

Jedynym kryterium szczegółowym opisującym podejście ewolucyjno-rynkowe częściej wybieranym w przeprowadzonych analizach empirycznych było podłoże konkurencji. 52\% ankietowanych wskazało przewagę kosztową lub wyróżnienie produktu; świadczy to o tym, że zarządzający badanymi organizacjami tkwią jeszcze w większości w erze dostosowywania się do wymogów klienta, w której myśl przewodnia brzmiała „wygrywa wydajniejszy i bardziej konkurencyjny”, a głównym problemem było to, jak zapewnić tani produkt i rozszerzyć rynek. 
Kolejnym zadaniem badawczym było znalezienie odpowiedzi na pytanie dotyczące skali i formy prowadzonej polityki zarządzania zasobami niematerialnymi przedsiębiorstw. Ankietowani potwierdzili, że w ich opinii o wartości rynkowej przedsiębiorstwa coraz bardziej decydują zasoby niematerialne (57\% wskazań) i dlatego dla efektywnego zarządzania organizacją istotne jest identyfikowanie bazy zasobów niematerialnych, jaką dysponuje firma (58\% wskazań).

Badani pracownicy często nie wiedzą, czy w ich przedsiębiorstwach w ramach polityki zarządzania zasobami niematerialnymi stosuje się identyfikację zasobów niematerialnych organizacji - 52\% respondentów nie jest w stanie odpowiedzieć na to pytanie, a tylko $34 \%$ badanych potwierdza identyfikowanie zasobów niematerialnych w ich firmach. Wyniki sugerują brak komunikacji w zakresie realizowania polityki zarządzania zasobami niematerialnymi, choć o jej istnieniu świadczą inne odpowiedzi. W ramach pytań odnoszących się do identyfikacji konkretnych zasobów w badanych przedsiębiorstwach wskazywano bowiem zasoby niematerialne. Zazwyczaj były to:

- kompetencje indywidualne (68\%),

- kompetencje organizacyjne (64\%),

- reputacja firmy (36\%),

- kontakty z partnerami strategicznymi (30\%).

Jeśli chodzi o źródła przewagi konkurencyjnej, w badanych organizacjach na pierwszy plan wysuwają się zasoby niematerialne (58\%), które mają niewielką przewagę nad materialnymi (52\%).

Wśród zasobów determinujących przewagę konkurencyjną badanych przedsiębiorstw wskazano w kolejności następujące:

- kompetencje w postaci wiedzy wspartej zbiorami informacji, umiejętności, doświadczenia i talentów pracowników - 74\%,

- postawy i zachowania pracownicze (lojalność, dyspozycyjność, kreatywność) i inne elementy kultury organizacji $-72 \%$,

- wizerunek firmy (znaki handlowe, historia, reputacja) - 65\%,

- finanse $-63 \%$,

- lokalizację (miejsce produkcji, świadczenia usług, sprzedaży, oryginalne historyczne budynki) $-61 \%$,

- sformalizowane relacje $\mathrm{z}$ otoczeniem (koncesje, certyfikaty, wynikające z umów uprzywilejowanie) $-56 \%$,

- niesformalizowane relacje z otoczeniem (wynikające z kontaktów osobistych, zaufania i lojalności) - 55\%,

- zapasy - 54\%,

- rzeczowy majątek trwały $-52 \%$,

- technologie informatyczne (autorskie, kosztowne oprogramowanie wspomagające technologie branżowe i procesy informacyjno-decyzyjne) $-47 \%$, 
- rutyny, rozwiązania wewnątrzorganizacyjne $-45 \%$,

- technologie branżowe - patenty, kosztochłonne rozwiązania high-tech lub o wartościach historycznych $-44 \%$,

- własne lub będące do dyspozycji zasoby naturalne (oryginalność właściwości fizykochemicznych) $-36 \%$.

Uzyskane odpowiedzi wskazują na dominującą, w opinii badanych, rolę zasobów niematerialnych, zwłaszcza najbardziej „miękkich” atutów organizacji. Potwierdzają więc one w praktyce idee, które już w latach 80. XX w. znalazły odzwierciedlenie w koncepcji modelu 7S T. Petersa i R. Watermana. Oddają również pierwszeństwo ,sercu” organizacji (jak jest nazywane przez nawigator Skandii) i podstawowemu katalizatorowi kapitału intelektualnego - kapitałowi ludzkiemu. Determinuje on, według wyników badań empirycznych, kondycję ścian metaforycznego domu (w postaci kapitału klienckiego - wizerunek, relacje, oraz kapitału organizacyjnego - rutyny wewnątrzorganizacyjne, technologie informatyczne i branżowe), a nade wszystko fundamentów przedsiębiorstwa. Uzasadnia to wcześniejsze wypowiedzi wskazujące na podejmowanie w badanych przedsiębiorstwach działań w zakresie identyfikacji kompetencji i relacji.

Ankietowani argumentują prowadzenie takiej polityki zarządzania zasobami w ich organizacjach nieprzewidywalnością sytuacji przedsiębiorstw i otoczenia oraz komunikowaną przez zarządzających świadomością konieczności budowania dokładnie tych zasobów niematerialnych w długim okresie.

Tabela 1. Zasoby decydujące o pozycji konkurencyjnej badanych przedsiębiorstw

\begin{tabular}{|l|c|c|}
\hline \multicolumn{1}{|c|}{ Zasoby } & Suma z rang & Mediana z rang \\
\hline Rzeczowy majątek trwały & 163 & 3 \\
\hline Finanse & 219 & 4 \\
\hline Zapasy & 99 & 3 \\
\hline Lokalizacja & 182 & 3 \\
\hline Zasoby naturalne & 76 & 2 \\
\hline Kompetencje & 266 & 5 \\
\hline Postawy i zachowania pracownicze & 213 & 4 \\
\hline Sformalizowane relacje z otoczeniem & 106 & 2 \\
\hline Niesformalizowane relacje z otoczeniem & 131 & 4 \\
\hline Wizerunek firmy & 208 & 4 \\
\hline Rutyny, rozwiązania wewnątrzorganizacyjne & 75 & 2 \\
\hline Technologie informatyczne & 130 & 3 \\
\hline Technologie branżowe & 156 & 4 \\
\hline
\end{tabular}

Źródło: opracowanie własne. 
Według istotności ankietowani wyróżnili kolejno następujące zasoby decydujące o przewadze konkurencyjnej weryfikowanych przedsiębiorstw: kompetencje, finanse, postawy i zachowania pracownicze, wizerunek firmy (tabela 1). Stąd jedynie nieznaczna, procentowa przewaga zasobów niematerialnych w kształtowaniu pozycji konkurencyjnej analizowanych firm.

Jedną z najistotniejszych kwestii pozostaje jednak długoletnia perspektywa gospodarowania zasobami badanych organizacji. Zarysowują ją odpowiedzi udzielone na pytanie dotyczące wskazania najważniejszych zasobów w przyszłości, na których rozwoju przedsiębiorstwa zamierzają się koncentrować (tabela 2).

Tabela 2. Kierunki rozwoju zasobów badanych przedsiębiorstw w przyszłości

\begin{tabular}{|l|c|c|}
\hline \multicolumn{1}{|c|}{ Zasoby } & Suma z rang & Mediana z rang \\
\hline Rzeczowy majątek trwały & 132 & 3 \\
\hline Finanse & 203 & 4 \\
\hline Zapasy & 99 & 3 \\
\hline Lokalizacja & 99 & 3 \\
\hline Zasoby naturalne & 61 & 3 \\
\hline Kompetencje & 267 & 4 \\
\hline Postawy i zachowania pracownicze & 195 & 4 \\
\hline Sformalizowane relacje z otoczeniem & 160 & 3 \\
\hline Niesformalizowane relacje z otoczeniem & 113 & 3 \\
\hline Wizerunek firmy & 178 & 3 \\
\hline Rutyny, rozwiązania wewnątrzorganizacyjne & 57 & 2 \\
\hline Technologie informatyczne & 172 & 4 \\
\hline Technologie branżowe & 137 & 4 \\
\hline
\end{tabular}

Źródło: opracowanie własne.

Wskazano, podobnie jak w odniesieniu do teraźniejszości, kompetencje oraz postawy i zachowania pracownicze, nie zapominając o finansach jako podstawowym elemencie przetrwania i rozwoju. Podkreślono również niesłabnącą rolę wizerunku firmy. Daje się zauważyć wyraźną tendencję dotyczącą nastawienia na kształtowanie relacji sformalizowanych, bo o ile obecnie relacje niesformalizowane zdają się być dominujące, to wysiłki skierowane na ich formalizację mogącą skutkować większą przewidywalnością i wymiernością ich rezultatów (rys. 2). Warte podkreślenia jest również deklarowanie inwestycji w technologie informatyczne. Na znaczeniu zdają się tracić zasoby materialne w postaci rzeczowego majątku trwałego, lokalizacji czy zasobów naturalnych. Spośród wskazanych przez badanych zasobów materialnych żadne nie uzyskały większej sumy rang w odniesieniu do przyszłych planów rozwojowych. 


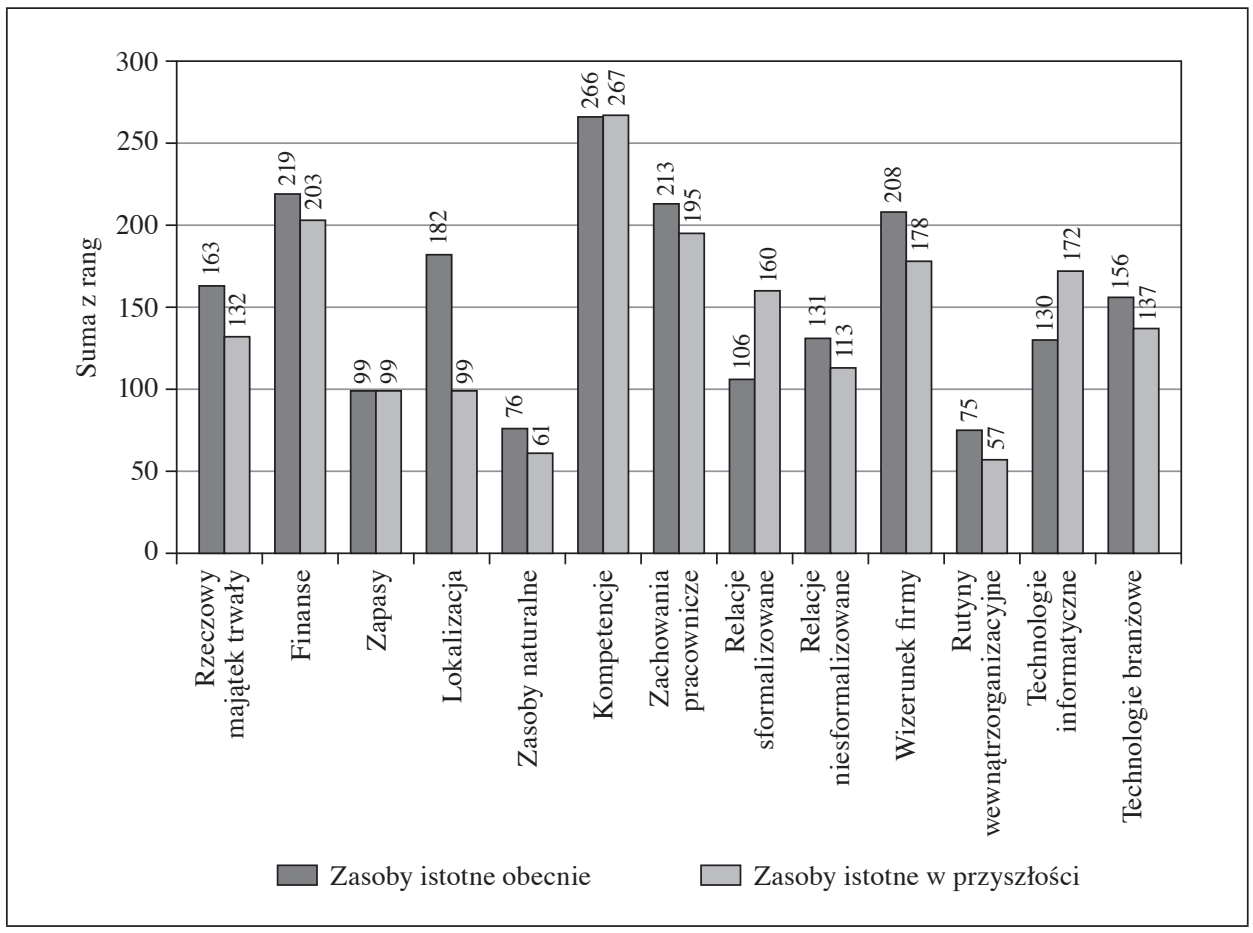

Rys. 2. Źródła przewagi konkurencyjnej badanych przedsiębiorstw obecnie i w przyszłości

Źródło: opracowanie własne.

Podsumowując, na podstawie przeprowadzonych badań pilotażowych można zauważyć, że w badanych organizacjach dominuje orientacja zasobowa, która per se nie zakłada przewagi zasobów niematerialnych. Obecnie, niemal w takim samym stopniu, o pozycji konkurencyjnej badanych firm decydują zasoby zarówno materialne, jak i niematerialne. Natomiast jeśli chodzi o plany dotyczące przyszłości, zasoby niematerialne zdecydowanie mają pierwszeństwo. Potwierdzają to wyniki innych badań empirycznych (zob. [Hidayati i in. 2012]), w których wyraźnie potwierdzono tezę, że orientacja na zasoby niematerialne wpływa na sukces przedsiębiorstw, zwłaszcza na rynkach wschodzących, a za taki uchodzi rynek w Polsce.

Oczywiście należy ostrożnie interpretować rezultaty badań ze względu na wielkość próby i wiedzę badanych, która jest uzależniona od efektywności komunikowania się w organizacji. Większość ankietowanych stanowili bowiem pracownicy niezaangażowani bezpośrednio $\mathrm{w}$ działania strategiczne przedsiębiorstw, na temat których się wypowiadali. Niemniej jednak nie należy odrzucać uzyskanych wyników - świadczą one o istnieniu orientacji zasobowej i posługiwaniu się przez 
zarządzających badanymi organizacjami językiem zasobów - tak ich przekaz odczytują respondenci. Właściwy przekaz oraz znajomość posiadanej przez organizację strategii wśród pracowników jest podstawą jej skutecznej realizacji. Spójności orientacji zasobowej między zarządzającymi a zarządzanymi dowodzi także fakt, że korelacje między reprezentowanym szczeblem zarządzania a udzielanymi odpowiedziami nie były statystycznie istotne. Wyniki tych badań stanowią więc obraz wspólny dla wszystkich zaangażowanych w działalność analizowanych przedsiębiorstw.

\section{Podsumowanie}

Przedstawiona w ogólnym zarysie specyfika zasobów niematerialnych przekonuje, że wskazanie uniwersalnych sposobów zarządzania nimi nie jest prostym zadaniem. Wnikliwa analiza bogatego dorobku literaturowego dotyczącego zasobów niematerialnych pozwala jednak rozwiązać wiele pojawiających się w praktyce problemów. Po pierwsze, w procesie zarządzania zasobami niematerialnymi powinno dążyć się do uzyskania dostępu do takiej ich ilości i jakości, aby w chwili pojawienia się szansy rozwojowej przekształcić je w kapitał intelektualny pozwalający w pełni tę szansę wykorzystać. Po drugie, należy przyjmować takie strategie zarządzania, aby jak największa część zasobów niematerialnych była spożytkowana jako kapitał intelektualny. Niewykorzystanie zasobów niematerialnych będących w dyspozycji organizacji to marnotrawienie możliwości rozwojowych, chyba że dany zasób traktowany jest jako rezerwowy na wypadek pojawienia się zagrożeń. Po trzecie, należy identyfikować i badać zarówno zasoby niematerialne, jak i kapitał intelektualny. Informacja o posiadanych zasobach niematerialnych, ich alokacji i poziomie wykorzystania jest podstawą podejmowania właściwych decyzji.

Nie należy jednak zapominać, że zasoby niematerialne posiadane w nadmiarze lub niewłaściwie wykorzystywane mogą ograniczać rozwój organizacji i tworzyć kategorię antyzasobów. Ich odpowiednie wykorzystanie zależy bezpośrednio od posiadania uzupełniających je zasobów materialnych [Villalonga 2004, s. 226].

Analiza przeprowadzonych badań empirycznych dowodzi występowania podejścia zasobowego w praktyce zarządzania organizacjami oraz coraz większej i rosnącej świadomości konieczności orientacji na zarządzanie zasobami niematerialnymi. Obecnie bowiem właśnie w nich upatruje się źródeł przewagi konkurencyjnej, a najczęściej wskazuje się kompetencje, postawy i zachowania pracownicze. Te z kolei determinują uzyskanie i utrzymanie przewagi funkcjonalnej, kulturowej i jakości zarządzania, zidentyfikowanych przez R. Maiera. Zauważyć można także zwiększające się znaczenie relacji, zarówno sformalizowanych, jak 
i niesformalizowanych, co potwierdza teoretyczne rozważania prowadzone w literaturze przedmiotu (zob. [Galbreath 2002, s. 118]), które współcześnie skutkują wyłanianiem się podejścia relacyjnego przeciwstawianego teorii zasobowej (zob. [Morawski 2017, s. 27]).

Wyniki przeprowadzonych wstępnych badań pilotażowych dowodzą występowania przejawów realizacji działań charakterystycznych dla poziomu strategicznego zarządzania zasobami niematerialnymi. Potwierdzają dążenia do ich raportowania oraz tworzenia dzięki nim efektu synergii. Prowadzenie polityki zarządzania zasobami niematerialnymi na poziomie operacyjnym znalazło również swe praktyczne potwierdzenie w identyfikacji działań skoncentrowanych na rozwoju konkretnych zasobów niematerialnych w postaci kompetencji czy kontaktów z partnerami strategicznymi. Rezultaty te wpisują się z kolei we wnioski z empirycznych analiz prowadzonych przez E. Shakinę i A. Barajasa [2015, s. 737], według których organizacje realizujące strategie ukierunkowane na rozwój konkretnych zasobów niematerialnych odnoszą większe sukcesy rynkowe niż przedsiębiorstwa nastawione na równomierną i stałą rozbudowę większości zasobów niematerialnych.

Zaprezentowane wyniki badań należy traktować wyłącznie poglądowo, gdyż mają wyraźne ograniczenia ze względu na wielkość próby badawczej i szczeble zarządzania reprezentowane przez większość respondentów. Przeprowadzone badania powinny być traktowane wyłącznie jako pilotażowe. Potwierdzają one istnienie orientacji zasobowej i uprawniają do prowadzenia właściwych badań naukowych dotyczących np. wpływu konkretnych zasobów niematerialnych na pozycję konkurencyjną i wartość organizacji w określonych sektorach lub praktycznej weryfikacji modeli pomiaru zasobów niematerialnych.

\section{Literatura}

Abu Bakar L.J., Ahmad H. [2010], Assesing the Relationship between Firm Resources and Product Innovation Performance. A Resource-based View, ,Business Process Management Journal", vol. 16, nr 3, https://doi.org/10.1108/14637151011049430.

Barney J.B. [1991], Firm Resources and Sustained Competitive Advantage, „Journal of Management", vol. 17, nr 1, https://doi.org/10.1177/014920639101700108.

Barney J.B., Ketchen Jr D.J., Wright M. [2011], The Future of Resource-based Theory: Revitalization or Decline?, ,Journal of Management”, vol. 37, nr 5, https://doi.org/ 10.1177/0149206310391805.

Basso L.F.C, Oliveira J.A.S. de, Kimura H., Braune E.S. [2015], The Impact of Intangibles on Value Creation: Comparative Analysis of Gu and Lev Methodology for the United States Software and Hardware Sector, „Investigaciones Europeas de Directión y Economia de la Empresa", vol. 21, nr 2, https://doi.org/10.1016/j.iedee.2014.09.001.

Bratnicki M. [2000], Podstawy wspótczesnego myślenia o zarzq̨dzaniu, Wydawnictwo Triada, Dąbrowa Górnicza.

Brilman J. [2002], Nowoczesne koncepcje i metody zarzqdzania, PWE, Warszawa. 
Czakon W. [2010], Zasobowa teoria firmy w krzywym zwierciadle, „Przegląd Organizacji”, nr 4.

Diefenbach T. [2006], Intangible Resources: A Categorial System of Knowledge and Other Intangible Assets, ,,Journal of Intellectual Capital”, vol. 7, nr 3, https://doi.org/ $10.1108 / 14691930610681483$.

Dudycz T. [2005], Zarzqdzanie wartościq przedsiębiorstwa, PWE, Warszawa.

Galbreath J. [2002], Twenty-first Century Management Rules: The Management of Relationships as Intangible Assets, ,Management Decisions”, vol. 40, $\mathrm{nr}$ 2, https://doi.org/ 10.1108/00251740210422794.

Galbreath J. [2005], Which Resources Matter the Most to Firm Success? An Exploratory Study of Resource-Based Theory, „Technovation”, vol. 25, nr 9, https://doi.org/ 10.1016/j.technovation.2004.02.008.

Gancarczyk M. [2015], Proces wzrostu przedsiębiorstwa w świetle podejścia zasobowego i teorii kosztów transakcyjnych, „Gospodarka Narodowa”, nr 5(279).

Godziszewski B. [2001], Zasobowe uwarunkowania strategii przedsiębiorstwa, Wydawnictwo Uniwersytetu Mikołaja Kopernika, Toruń.

Grant R.M. [1991], The Resource-based Theory of Competitive Advantage: Implication for Strategy Formulation, „California Management Review”, vol. 33, nr 3, https://doi. org/10.2307/41166664.

Grant R.M. [2001], The Resource-based Theory of Competitive Advantage: Implication for Strategy Formulation, „California Management Review”, Spring.

Hall R. [1992], The Strategic Analysis of Intangible Resources, „Strategic Management Journal", vol. 13, nr 2, https://doi.org/10.1002/smj.4250130205.

Hall R. [1993], A Framework Linking Intangible Resources and Capabilities to Sustainable Competitive Advantage, ,Strategic Management Journal”, vol. 14, nr 8, https://doi. org/10.1002/smj.4250140804.

Hidayati A., Fanani Z., Prasetyo K., Mardijuwono A.W. [2012], The Impact of Intangible Asset on Firm's Competitive Advantage and Market Value: Empirical Examination from Emerging Market, Proceedings of Bangkok Conference, http://www.wbiconpro. com/110-Zaenal.pdf (data dostępu: 19.09.2017).

Hopfenbeck W., Müller M., Peisl T. [2001], Wissensbasiertes Management. Ansätze und Strategien Unternehmensführung in der Internet-Ökonomie, Verlag Moderne Industrie, Landsberg/Lech.

Kamasak R. [2017], The Contribution of Tangible and Intangible Resources, and Capabilities to a Firm's Profitability and Market Performance, „European Journal of Management and Business Economics”, vol. 26, nr 2, https://doi.org/10.1108/ejmbe-07-2017-015.

Kozłowski J. [2002], Intellectual Capital, Knowledge Management and Intelligent Products in the Light of Catalogue and Abstract Data Basis [w:] Knowledge Café for Intellectual Products and Intellectual Capital, red. S. Kwiatkowski, C. Stowe, Leon Koźmiński Academy of Entrepreneurship and Management, Warszawa.

Kristandl G., Bontis N. [2007], Constructing a Definition for Intangibles Using the Resources Based View of the Firm, „Management Decision”, vol. 45, nr 9, https://doi. org/10.1108/00251740710828744.

Krupski R. [2011], Orientacja zasobowa w badaniach empirycznych. Identyfikacja horyzontu planowania rynkowych i zasobowych wielkości strategicznych, Praca Naukowa Wałbrzyskiej Wyższej Szkoły Zarządzania i Przedsiębiorczości, Seria: Zarządzanie, Wałbrzych. 
Krupski R. [2012], Rozwój szkoły zasobów zarzq̨dzania strategicznego, „Przegląd Organizacji”, $\mathrm{nr} 4$.

Krupski R. [2014], Zasoby niematerialne jako główny składnik strategii przedsiębiorstwa działajacego $w$ turbulentnym, nieprzewidywalnym otoczeniu, „Organizacja i Kierowanie", nr 1A.

Krupski R., Niemczyk J., Stańczyk-Hugiet E. [2009], Koncepcje strategii organizacji, PWE, Warszawa.

Kumulu O. [2014], The Effect of Intangible Resources and Competitive Strategies on the Export Performance of Small and Medium Sized Enterprises, „Procedia - Social and Behavioral Sciences", vol. 150, https://doi.org/10.1016/j.sbspro.2014.09.004.

Kuzel M. [2016], Konfiguracja zasobów w ramach ponadnarodowych struktur polskich przedsiębiorstw - inwestorów zagranicznych jako czynnik ich międzynarodowej konkurencyjności, „Przegląd Organizacji”, nr 2.

Leśniewski M.A. [2014], Konkurencyjność zasobowa przedsiębiorstw, „Ekonomika i Organizacja Przedsiębiorstwa", nr 4.

Lev B. [2003], Intangible Assets Concepts and Measurements, New York University Press, New York.

Maier R. [2002], Knowledge Management Systems. Informatio and Communication Technologies for Knowledge Management, Springer-Verlag, Berlin-Heidelberg.

Marr B. [2005], Strategic Management of Intangible Value Drivers, ,Handbook of Business Strategy", vol. 6, nr 1, https://doi.org/10.1108/08944310510557161.

Morawski M. [2017], Podejście relacyjne w zarzqdzaniu wiedza, ,Studia Ekonomiczne Regionu Łódzkiego", nr 24.

Moszkowicz M. [2005], Zarzqdzanie strategiczne jako koncepcja zarzqdzania [w:] Zarzqdzanie strategiczne. Systemowa koncepcja biznesu, red. M. Moszkowicz, PWE, Warszawa.

Obłój K. [2001], Strategia organizacji, PWE, Warszawa.

Obłój K. [2007], Strategia organizacji, wyd. 2 zm., PWE, Warszawa.

Penrose E.T. [1959], The Theory of the Growth of the Firm, Wiley, New York.

Peteraf M.A. [1993], The Cornerstones of Competitive Advantage: A Resource-based View, „Strategic Management Journal”, vol. 14, nr 3, https://doi.org/10.1002/smj. 4250140303.

Pietruszka-Ortyl A. [2008], Specyfika niematerialnych zasobów organizacji, „Zeszyty Naukowe Uniwersytetu Ekonomicznego w Krakowie", nr 765.

Pietruszka-Ortyl A. [2017], Intangible Resources in Strategic Management of Organizations, „Zeszyty Naukowe Uniwersytetu Przyrodniczo-Humanistycznego w Siedlcach”, nr 114, Seria: Administracja i Zarządzanie, nr 41.

Pietruszka-Ortyl A., Mikuła B. [2010], Studium niematerialnych zasobów organizacji, „Zeszyty Naukowe Uniwersytetu Ekonomicznego w Krakowie”, nr 820.

Sánchez P., Chaminade C., Olea M. [2000], Management of Intangibles. An Attempt to Build a Theory, ,Journal of Intellectual Capital”, vol. 1, nr 4, https://doi.org/10.1108/ 14691930010359225.

Sequeira C.A., Fernández E.F., Borges M.C. [2009], The Best Returns Come from Intangible Resources: An Integrated Approach, „VINE: The Journal of Information and Knowledge Management Systems", vol. 39, nr 1, https://doi.org/10.1108/ 03055720910962416.

Shakina E., Barajas A. [2015], Intangible-Intensive Profile of a Company: The Key to Outperforming, ,Journal of Intellectual Capital”, vol. 16, nr 4, https://doi.org/10.1108/ jic-03-2015-0025. 
Skowronek-Mielczarek A. [2012], Zasoby w rozwoju przedsiębiorstwa, „Studia i Prace Kolegium Zarządzania i Finansów", z. 121.

Stankiewicz M.J. [2002], Konkurencyjność przedsiębiorstwa. Budowanie konkurencyjności przedsiębiorstwa $w$ warunkach globalizacji, Towarzystwo Naukowe Organizacji i Kierownictwa - Stowarzyszenie Wyższej Użyteczności „Dom Organizatora”, Toruń.

Stewart T.A. [2001], The Wealth of Knowledge. Intellectual Capital and the Twenty-First Century Organization, Nicholas Brealey Publishing, London.

Urbanowska-Sojkin E. [2013], Zasobowy kontekst sukcesu przedsiębiorstwa, „Zarządzanie i Finanse", nr 1/11.

Villalonga B. [2004], Intangible Resources, Tobin's q, and Sustainability of Performance Differences, ,Journal of Economic Behavior and Organization”, vol. 54, nr 2, https:// doi.org/10.1016/j.jebo.2003.07.001.

Wit B. de, Meyer R. [2007], Synteza strategii. Tworzenie przewagi konkurencyjnej przez analizowanie paradoksów, PWE, Warszawa.

Wojciechowska M.D. [2016], Intangible Organizational Resources in Polish Libraries. Results of Research among Directors and Executives, „Library Management”, vol. 37, nr 1/2, https://doi.org/10.1108/lm-08-2015-0055.

Zakrzewska-Bielawska A. [2013], Zasobowe uwarunkowania koopetycji w przedsiębiorstwach high-tech, „Przegląd Organizacji”, nr 2.

Zigan K., Zeglat D. [2010], Intangible Resources in Performance Management Systems of the Hotel Industry, „Facilities”, vol. 28, nr 13/14, https://doi.org/10.1108/02632 771011083667.

Ziółkowska B. [2012], Podejście zasobowe w strategicznym zarzqdzaniu wartościq przedsiębiorstwa, ,Zeszyty Naukowe Politechniki Częstochowskiej. Zarządzanie”, nr 6.

\section{Resource-based Orientation in the Practice of Enterprises Management - Discussion of the Results of Empirical Research}

(Abstract)

One consequence of the emergence of a knowledge economy has been the creation of resource-based theory and greater concentration on the growing importance of an organisation's intangible resources. The redefinition of resources has resulted in many proposals for how they should be classified, and how conceptualisation based on their specific characteristics should be designated.

The aim of the study was to synthesize the subject literature in terms of the specifics of intangible resources and to answer the question of whether, in the respondents' opinions, the companies they describe have a resource-based orientation.

The results of empirical analyses presented in the paper confirm that the resource approach predominates in organisational management practice. They also pointed to the growing awareness of the need for an orientation towards intangible resource management. At present and in the future, most often in the competencies, attitudes and behaviours of employees, the image of the company and its relationships are and will even more come to be seen as the sources of sustainable competitive advantage for organisations.

Keywords: knowledge economy, intangible resources, resource-based theory, strategy of the organisation, empirical studies. 